\title{
К ВОПРОСУ О ПОЛУЧЕНИИ РАЗРЕШЕНИЯ НА СТРОИТЕЛЬСТВО ХРАМА В ПОРЕФОРМЕННОЙ РОССИИ (ПО МАТЕРИАЛАМ МОСКОВСКОГО УЕЗДА МОСКОВСКОЙ ГУБЕРНИИ)
}

\author{
С. Е. ФЕДОсЕЕВА
}

\begin{abstract}
В статье реконструируется процесс получения разрешения на строительство нового храма в пореформенный период. Источником для данного исследования являются архивные дела о строительстве церквей, хранящиеся в Центральном государственном архиве г. Москвы. Автор выделяет три этапа в описанном процессе: подача документов, проверка информации и вынесение решения. Сначала просители подавали прошение с подробным указанием сведений о себе, о причинах постройки новой церкви, об источниках и размере финансирования, о наличии земельного участка под постройку, о посвящении алтарей, а также план здания и местности. В духовной консистории вся эта информация обрабатывалась, проверялась и дополнялась необходимыми данными. На их основе заседание присутствия принимало решение о разрешении или отказе на постройку храма. Автор приходит к выводу, что критерием, которым руководствовалась духовная власть при принятии решения, было материальное обеспечение духовенства, способность будущих прихожан денежно обеспечить строительство церкви, содержание ее и причта. Описанный в статье процесс помогает дополнить знания о создании приходов, а также понять глобальность проблемы обеспечения клира, влияющей даже на такую сторону жизни прихода.
\end{abstract}

В конце XIX - начале XX в. в Российской империи наблюдался рост количества и численности приходов, что выражалось как в расширении и перестройке старых церквей, так и в постройке новых. Так, в Московском уезде Московской губернии, который кольцом опоясывал первопрестольную, в пореформенный период было построено 52 церкви (36 каменных и 16 деревянных), что составляло почти треть храмов уезда (см. табл. 1$)^{1}$.

таблица 1

Первичное строительство. Храмы, построенные впервые

(т. е. с открытием нового прихода или приписные)

\begin{tabular}{|c|l|l|c|c|c|}
\hline № & \multicolumn{1}{|c|}{ Название церкви } & \multicolumn{1}{|c|}{ Село } & Материал & Округ & $\begin{array}{c}\text { Время } \\
\text { постройки }\end{array}$ \\
\hline 1 & Преображенская & Богородское & камень & 1 & $1877-1880$ \\
\hline 2 & $\begin{array}{l}\text { Богородице-Рождествен- } \\
\text { ская }\end{array}$ & Никольское-Трубецкое & камень & 1 & $1858-1862$ \\
\hline
\end{tabular}

${ }^{1}$ Московский уезд по состоянию на начало XX в. состоял из 7 благочиннических округов, в нем было 149 приходских храмов. Курсивом выделены приписные церкви. 
Продолжение таблицы 1

\begin{tabular}{|c|c|c|c|c|c|}
\hline № & Название церкви & Село & Материал & Округ & $\begin{array}{c}\text { Время } \\
\text { постройки }\end{array}$ \\
\hline 3 & Сергиевская & $\begin{array}{l}\text { Шереметьевская, плат- } \\
\text { форма Московско-Ка- } \\
\text { занской железной дороги }\end{array}$ & дерево & 1 & $1901-1903$ \\
\hline 4 & $\begin{array}{l}\text { Петропавловская (припис- } \\
\text { ная к Влахернской иеркви, } \\
\text { село Влахернское-Кузьмин- } \\
\kappa и)\end{array}$ & Люблино, сельцо & дерево & 1 & 1872 \\
\hline 5 & Троицкая & Наташино, поселок & дерево & 1 & 1912 \\
\hline 6 & Александро-Невская & $\begin{array}{l}\text { Бирюлево, станция } \\
\text { Рязано-Уральской желез- } \\
\text { ной дороги }\end{array}$ & дерево & 2 & $1911-1912$ \\
\hline 7 & Николаевская & Павшино & камень & 4 & $1866-1873$ \\
\hline 8 & $\begin{array}{l}\text { Троицкая, и при ней } \\
\text { церкви: }\end{array}$ & $\begin{array}{l}\text { При Казанском Голо- } \\
\text { винском общежительном } \\
\text { женском монастыре }\end{array}$ & камень & 4 & $1885-1887$ \\
\hline 9 & Казанская & Там же & дерево & 4 & 1882 \\
\hline 10 & $\begin{array}{l}\text { Всемилостивого Спаса, до- } \\
\text { мовая }\end{array}$ & Там же & дерево & 4 & 1872 \\
\hline 11 & $\begin{array}{l}\text { Мученицы Акилины, домо- } \\
\text { вая, больничная }\end{array}$ & Там же & камень & 4 & 1893 \\
\hline 12 & «Утоли моя печали» & $\begin{array}{lr}\text { При } & \text { Александро- } \\
\text { Мариинском } & \text { Марфин- } \\
\text { ском приюте } & \\
\end{array}$ & камень & 4 & $1884-1885$ \\
\hline 13 & Филаретовская & $\begin{array}{l}\text { При Ермаковской бога- } \\
\text { дельне, что за Трехгорной } \\
\text { заставой }\end{array}$ & камень & 5 & $1885-1889$ \\
\hline 14 & & & дерево & 6 & 1871 \\
\hline 15 & ьоголюоская & пушкино, станция & камень & 6 & $1906-1913$ \\
\hline 16 & $\begin{array}{l}\text { Гребневская (приписная к } \\
\text { Боголюбской церкви, стан- } \\
\text { ция Пушкино) }\end{array}$ & Клязьма, платформа & дерево & 6 & 1902 \\
\hline 17 & $\begin{array}{l}\text { Николо-Алексеевская (при } \\
\text { Гребневской церкви) }\end{array}$ & & камень & 6 & $1913-1916$ \\
\hline 18 & $\begin{array}{l}\text { Донской Божьей Матери } \\
\text { (приписная к Благовещен- } \\
\text { ской иеркви, село Тайнин- } \\
\text { ское) }\end{array}$ & Перловка, станция & дерево & 6 & $1895-1897$ \\
\hline 19 & Преображенская & $\begin{array}{l}\text { При фабрике Черныше- } \\
\text { вых }\end{array}$ & дерево & 6 & $1894-1896$ \\
\hline 20 & Покровская & Черкизово на Клязьме & камень & 6 & 1903 \\
\hline
\end{tabular}


С. Е. Федосеева. К вопросу о получении разрешения на строительство храма в пореформенной России...

Продолжение таблищы 1

\begin{tabular}{|c|l|l|c|c|c|}
\hline \multirow{2}{*}{$№$} & \multicolumn{1}{|c|}{ Название церкви } & \multicolumn{1}{|c|}{ Село } & Материал & Округ & $\begin{array}{c}\text { Время } \\
\text { постройки }\end{array}$ \\
\hline 21 & $\begin{array}{l}\text { Богородицкая (иконы } \\
\text { Божией Матери) «Неча- } \\
\text { янная радость») }\end{array}$ & Марьина роща & камень & 6 & $1899-1904$ \\
\hline 22 & Андриановская & $\begin{array}{l}\text { Лосиноостровская, стан- } \\
\text { ция Ярославской желез- } \\
\text { ной дороги }\end{array}$ & камень & 6 & $1914-1916$ \\
\hline 23 & Николаевская & Ангелово & камень & 7 & 1906 \\
\hline 24 & Сергиевская & $\begin{array}{l}\text { На хуторе Ивановского } \\
\text { девичьего монастыря }\end{array}$ & дерево & 7 & 1893 \\
\hline 25 & Троицкая & $\begin{array}{l}\text { Сходня, станция Никола- } \\
\text { евской железной дороги }\end{array}$ & дерево & 7 & 1903 \\
\cline { 3 - 6 } & Камень & 7 & 1910 \\
\hline 26 & Серафимовская & $\begin{array}{l}\text { Катюшки, деревня (на } \\
\text { хуторе Московского Ни- } \\
\text { китского женского мона- } \\
\text { стыря) }\end{array}$ & 7 & $1904-1905$ \\
\hline
\end{tabular}

Задача данной статьи - реконструировать процесс получения разрешительных документов для строительства храма. Нами будут рассмотрены лишь случаи создания новой церкви.

Процесс получения разрешения на строительство храма условно можно разделить на несколько этапов: подача пакета необходимых для начала строительства документов в канцелярию архиерея; рассмотрение документов в Консистории; оформление итогового протокола с вынесенным решением по делу.

Весь процесс получения разрешительных документов регламентировался Уставом духовных консисторий ${ }^{2}$. Прошение с просьбой о разрешении постройки нового храма подавалось на имя правящего 3 или викарного ${ }^{4}$ архиерея в Московскую Духовную Консисторию. В нем указывались те данные, которые необходимы были Консистории для понимания ситуации во всей полноте и для принятия решения, а именно:

1) сведения об инициаторах строительства;

2) причина, по которой необходимо построить храм;

3) источники и размеры финансирования строительства, отделки, убранства и дальнейшего содержания причта и церковного здания;

4) наличие и источник предоставления земли под храм;

5) данные о посвящении алтарей;

6) план здания и местности.

${ }^{2}$ См.: Ливанов Ф. В. Устав духовных консисторий, поясненный 1. Полным собранием свода законов Российской империи. 2. Статьями духовного регламента. 3. Указами Святейшего Синода... СПб., 1871.

${ }^{3}$ ЦГА Москвы. ЦХД до 1917 года. Ф. 203. Оп. 484. Д. 6. Л. 1.

${ }^{4}$ Там же. Оп. 449. Д. 8. Л. 1. 
Подачи документов для первичного или вторичного строительства храмов существенно различались. Если при восстановлении или реконструкции храма (по причине пожара или другого бедствия ${ }^{5}$ прошения обычно были подписаны приходским священником (или несколькими клириками) и церковным старостой, чьи полномочия в приходе были достаточно велики, то при строительстве новых храмов на пустом месте прошение писалось местными жителями-мирянами. Как правило, это были дачевладельцы, число которых в конце XIX - начале XX в. значительно увеличивается в рассматриваемом уезде ${ }^{6}$ Ж Живущие в уезде землевладельцы и крестьяне также участвовали в деле церковного строительства. Реже инициаторами строительства выступали купцы, которые на свои средства готовы были поставить храм и в связи с этим лично подавали прошение?

В прошении важным моментом было указание причины построения новой церкви. Как правило, при первичном строительстве основанием для возведения храма являлось увеличение числа населения и неспособность старой приходской церкви вмещать всех прихожан. Вторичное строительство предполагало возведение нового церковного здания на месте прежнего, сгоревшего или подвергшегося иным бедствиям.

Ктиторы любили приурочить строительство своей церкви к памятным событиям, связанным с императорской семьей (дни коронаций или памяти святых покровителей членов Августейшей семьи ${ }^{8}$. Правда, как правило, это было не причиной строительства храма, а скорее, поводом, указывая который просители, возможно, надеялись на более благосклонное отношение к их просьбе, убыстрение процесса получения итогового протокола.

Строительство храма было делом дорогостоящим. Ни государство, ни епархия финансово не помогали в нем будущим прихожанам. Иногда находились богатые ктиторы - купцы или помещики, которые жертвовали большие суммы. Впрочем, по нашим данным, неизвестно ни одного случая полной оплаты строительства одним человеком. Но, как правило, будущие рядовые прихожане - дачевладельцы, крестьяне - вкладывали свои средства в возведение храма. Для этого во многих местах избирались строительные комитеты, которым выдавались приходо-расходные книги для сбора и записи пожертвований и которые руководили в дальнейшем процессом постройки церкви 9 .

Помимо наличия денежных средств на постройку здания церкви просители должны были указать и наличие земельного участка под строительство и его происхождение. Как правило, участок жертвовали крестьяне ${ }^{10}$. Но иногда часть сво-

${ }^{5}$ ЦГА Москвы. ЦХД до 1917 года. Ф. 203. Оп. 460. Д. 3. Священник храма в с. Братеево просит разрешения на постройку каменного храма, так как существующий деревянный стоит очень близко к Москве-реке и грозит обрушиться вместе с берегом из-за обмывов.

${ }^{6}$ См.: Осипов $E$. $A$. Очерк статистики народонаселения Московского уезда // Сборник статистических сведений по Московской губернии. М., 1878. Т. 1. Вып. 11; Богословский В. Г. Очерк движения народонаселения Московского уезда Московской губернии. М., 1900.

${ }^{7}$ ЦГА Москвы. ЦХД до 1917 года. Ф. 203. Оп. 468. Д. 2. Л. 1 - 1 об. Прошение купцов о строительстве храма в Черкизово.

${ }^{8}$ Там же.

${ }^{9}$ Там же. Оп. 484. Д. 6. Л. 2.

${ }^{10}$ Там же. Оп. 449. Д. 8. Л. 1 об. 
их земельных угодий отдавали под постройку храма крупные землевладельцы. «Земля... в количестве целой десятины жертвуется главным нашим помещиком Г. Скальским» ${ }^{11}$ для постройки храма в дачном поселке Наташино, а при станции Сходня будущий храм планировалось поставить на земле почетного гражданина Христофора Семеновича Леденцова ${ }^{12}$.

В прошении необходимых документов просители обычно указывали и предполагаемое посвящение алтарей будущей церкви («...мы имеем неотложную нужду в построении храма во имя и преславную честь ПРЕСВЯТЫЯ ТРОИЦЫ» $\left.{ }^{13}\right)$, также как и материал, из которого она будет возведена (то есть будет ли храм каменный ${ }^{14}$ или деревянный $\left.{ }^{15}\right)$.

В большинстве случаев главные престолы были посвящены Господским и Богородским праздникам, а уже придельные храмы освящали в честь святых (см. табл. 2).

Таблииа 2

Посвящение престолов церквей, построенных в пореформенный период

\begin{tabular}{|c|c|c|}
\hline Название церкви & $\begin{array}{c}\text { Количество } \\
\text { приделов }\end{array}$ & Место строительства \\
\hline \multicolumn{3}{|c|}{ В честь Господских праздников } \\
\hline Всемилостивого Спаса & 1 & $\begin{array}{l}\text { • при Казанском Головинском общежительном } \\
\text { женском монастыре, домовая }\end{array}$ \\
\hline Преображенская & 2 & $\begin{array}{l}\text { - Богородское } \\
\text { • при фабрике Чернышевых }\end{array}$ \\
\hline Троицкая & 3 & $\begin{array}{l}\text { - Наташино, поселок } \\
\text { • при Казанском Головинском общежительном } \\
\text { женском монастыре } \\
\text { • Сходня, станция Николаевской железной дороги }\end{array}$ \\
\hline ВСЕГО & 6 & \\
\hline \multicolumn{3}{|c|}{ В честь Богородичных праздников } \\
\hline Боголюбская & 2 & $\begin{array}{l}\text { - Павшино (в приходе Николаевской церкви) } \\
\text { • Пушкино, станция }\end{array}$ \\
\hline $\begin{array}{l}\text { Богородице-Рождест- } \\
\text { венская }\end{array}$ & 1 & • Никольское-Трубецкое \\
\hline Гребневская & 1 & $\begin{array}{l}\text { • Клязьма, платформа (приписная к Боголюбской } \\
\text { церкви станции Пушкино) }\end{array}$ \\
\hline Донская & 1 & $\begin{array}{l}\text { - Перловка, станция (приписная к Благовещен- } \\
\text { ской церкви села Тайнинское) }\end{array}$ \\
\hline Казанская & 1 & $\begin{array}{l}\text { • при Казанском Головинском общежительном } \\
\text { женском монастыре }\end{array}$ \\
\hline Покровская & 1 & - Черкизово на Клязьме \\
\hline «Нечаянная радость» & 1 & - Марьина роща \\
\hline
\end{tabular}

${ }^{11}$ ЦГА Москвы. ЦХД до 1917 года. Ф. 203. Оп. 484. Д. 6. Л. 1 об.

${ }^{12}$ Там же. Оп. 470. Д. 8. Л. $1-1$ об.

${ }^{13}$ Там же. Оп. 484. Д. 6. Л. 1.

${ }^{14}$ Там же. Оп. 449. Д. 9. Л. 1 об.

${ }^{15}$ ЦГА Москвы ЦХД до 1917 года. Ф. 203. Оп. 449. Д. 8. Л. 2. 
Продолжение таблицы 2

\begin{tabular}{|c|c|c|}
\hline «Утоли моя печали» & 1 & $\begin{array}{l}\text { • при Александро-Мариинском Марфинском } \\
\text { приюте }\end{array}$ \\
\hline ВСЕГО & 9 & \\
\hline \multicolumn{3}{|r|}{ В честь святых } \\
\hline $\begin{array}{l}\text { Святых Адриана и На- } \\
\text { талии }\end{array}$ & 1 & $\begin{array}{l}\text { • Лосиноостровская, станция Ярославской же- } \\
\text { лезной дороги }\end{array}$ \\
\hline Мученицы Акилины & 1 & $\begin{array}{l}\text { • при Казанском Головинском общежительном } \\
\text { женском монастыре, домовая, больничная }\end{array}$ \\
\hline $\begin{array}{l}\text { Святого благоверного } \\
\text { князя Александра Не- } \\
\text { вского }\end{array}$ & 1 & $\begin{array}{l}\text { • Бирюлево, станция Рязано-Уральской железной } \\
\text { дороги }\end{array}$ \\
\hline $\begin{array}{ll}\text { Святителя } & \text { Алексия, } \\
\text { митрополита } & \text { Москов- } \\
\text { ского } & \end{array}$ & 1 & $\begin{array}{l}\text { • Придельная - Клязьма (платформа), в приходе } \\
\text { Гребневской церкви (приписная к Боголюбской } \\
\text { церкви, станция Пушкино). Не освящена }\end{array}$ \\
\hline $\begin{array}{l}\text { Великомученика Геор- } \\
\text { гия Победоносца }\end{array}$ & 1 & $\begin{array}{l}\text { - Придельная - Боголюбская церковь в селе Пав- } \\
\text { шино (в приходе церкви Николаевская) }\end{array}$ \\
\hline $\begin{array}{l}\text { Святого пророка Бо- } \\
\text { жия Илии }\end{array}$ & 1 & $\begin{array}{l}\text { • Придельная - Боголюбская церковь в селе Пав- } \\
\text { шино (в приходе церкви Николаевская) }\end{array}$ \\
\hline $\begin{array}{l}\text { Святителя Иоанна } \\
\text { Новгородского }\end{array}$ & 1 & $\begin{array}{l}\text { - Придельная - Богородицкая (иконы Божией } \\
\text { Матери «Нечаянная радость») Марьина роща }\end{array}$ \\
\hline $\begin{array}{l}\text { Святителя } \\
\text { Чудотворца }\end{array}$ & 6 & $\begin{array}{l}\text { - Ангелово } \\
\text { • Пушкино, станция } \\
\text { • Клязьма (платформа), в приходе Гребневской } \\
\text { церкви (приписная к Боголюбской церкви, стан- } \\
\text { ция Пушкино). Не освящена } \\
\text { • Придельный - Покровская церковь, Черкизово } \\
\text { на Клязьме } \\
\text { • Придельный - Богородицкая (иконы Божией } \\
\text { Матери «Нечаянная радость») в Марьиной роще } \\
\text { • Придельный - Троицкая каменная церковь при } \\
\text { станции Сходня (сначала у деревянной) }\end{array}$ \\
\hline $\begin{array}{l}\text { Святых апостолов Пе- } \\
\text { тра и Павла }\end{array}$ & 1 & $\begin{array}{l}\text { - Люблино, сельцо (приписная к Влахернской } \\
\text { церкви села Влахернское-Кузьминки) }\end{array}$ \\
\hline $\begin{array}{l}\text { Святого преподобного } \\
\text { Сергия Радонежского }\end{array}$ & 3 & $\begin{array}{l}\text { • Шереметьевская, платформа Московско-Казан- } \\
\text { ской железной дороги } \\
\text { • на хуторе Ивановского девичьего монастыря } \\
\text { • Придельный - Покровская церковь, Черкизово } \\
\text { на Клязьме }\end{array}$ \\
\hline $\begin{array}{l}\text { Святого преподобного } \\
\text { Серафима Саровского }\end{array}$ & 1 & $\begin{array}{l}\text { • Катюшки, деревня. На хуторе Московского Ни- } \\
\text { китского женского Монастыря }\end{array}$ \\
\hline $\begin{array}{l}\text { Праведного Филарета } \\
\text { Милостивого }\end{array}$ & 1 & $\begin{array}{l}\text { • при Ермаковской богадельне, что за Трехгорной } \\
\text { заставой }\end{array}$ \\
\hline $\begin{array}{l}\text { ВСЕГО } \\
\text { Из них придельных }\end{array}$ & $\begin{array}{c}19 \\
8\end{array}$ & \\
\hline
\end{tabular}

Среди последних самым почитаемым был святитель Николай Чудотворец, в честь которого в рассматриваемый период среди новопостроенных храмов было заложено шесть престолов (из них три придельных). Святой преподобный Сер- 
гий Радонежский был покровителем трех престолов в новых храмах Московского уезда (1 придельный). Посвящение церкви зависело в основном от желания прихожан, и именные посвящения встречались, как правило, в честь святых покровителей ктиторов храма.

В прошении указывалось, какой будет будущая церковь - каменной или деревянной. Согласно пояснениям к уставу духовных консисторий сооружаемые церкви должны быть каменными. Но «из общего правила поставляется следующее изъятие: разрешается повсеместно строить деревянные церкви, не только там, где нет необходимых для каменного построения материалов, но и везде, где прихожане не имеют средств к возведению новых каменных церквей... (Т. XII, уст. строит. ст. 215)» ${ }^{16}$. Поэтому епархиальное начальство часто шло навстречу малоимущим просителям и разрешало строить деревянные церкви, к тому же, как правило, такие церкви становились приписными, что было хорошо, потому что приход в таком случае не делился и обеспечение старого причта не уменьшалось. Стоит отметить, что из 36 новопостроенных каменных храмов лишь два стали приписными, что, безусловно, еще раз иллюстрирует тот факт, что население, способное построить каменный храм, могло прокормить и самостоятельный причт в нем. Деревянные храмы ставились в том случае, если нужна была небольшая церковь для маленького прихода или для посещения ее только в летние месяцы (последнее было очень актуально для дачников).

Архитектурный план церковного здания и план прилегающей местности, как правило, прилагали к прошению. Для их составления можно было обратиться за помощью к епархиальному архитектору, в чьи обязанности входило выполнение данной работы (вместо окладного жалованья ему выдавалось определенное вознаграждение за труды - процент от сумм, затраченных на постройку $\left.{ }^{17}\right)$. Но иногда такие планы выполнялись по знакомству. Например, среди дачников у станции Сходня, которые решили просить о строительстве в их местности церкви, нашелся один архитектор (Флегонт Воскресенский), «который труд свой по постройке храма жертвует безвозмездно» ${ }^{18}$. В делах архитектурные планы не сохранились, видимо потому, что отсылались обратно просителям, для того чтобы по ним строить.

Поступившее в Консисторию прошение обрабатывалось, информация, в нем содержащаяся, проверялась, а недостающая запрашивалась в соответствующих инстанциях.

Информация о просителях, которая, согласно форме прошения, указывалась в его шапке, Консисторию практически не интересовала, а потому она не подвергалась проверке. Скорее всего, не было причин сомневаться в истинности сообщаемых просителями требований. Кроме того, эти данные практически не влияли на принятие решения Консисторией.

${ }^{16}$ Ливанов Ф. В. Устав духовных консисторий, поясненный... С. 58.

${ }^{17}$ Именной, объявленный Сенату Святейшим Синодом 13 октября о вознаграждении епархиальных архитекторов $1 \%$ за составление планов и смет и за наблюдение за работами // Полное собрание законов Российской империи. Собрание второе. СПб., 1875. T. XLVII. Отд. 1. 1872. С. 993.

${ }^{18}$ ЦГА Москвы. ЦХД до 1917 года. Ф. 203. Оп. 470. Д. 8. Л. 1. 
Духовные власти интересовал прежде всего вопрос о том, действительно ли новая церковь практически необходима в данной местности. Проверялось это двумя путями. Во-первых, посылался указ благочинному, в котором ему предписывалось выяснить необходимость строительства нового храма. Ответы благочинных на подобные вопросы сохранились в некоторых архивных делах: «В исполнение Указа... честь имею... донести, что в сельце Богородском находятся до двух сот дач и живущих в оных дачах около 1000 душ Православных, так как означенные дачи находятся от ближайших церквей в довольно дальнем расстоянии; посему я со своей стороны нахожу нужным, для означенного сельца, выстроить Церковь на средства, какие указываются в Указе 1877 года июля 18 дня» ${ }^{19}$. Во-вторых, кроме данных от благочинного, Консистория изучала справки по клировым ведомостям тех храмов, в приходе которых состояло данное поселение, или тех, к которым планировалось храм приписать. Из них выписывалась информация о составе прихода, потому что при строительстве новой самостоятельной церкви прихожане отделялись от других приходов. Таким образом, проверка совершалась по донесениям духовной власти на местах и на основании отчетных данных, имеющихся в консистории, которыми проверялся первый источник информации. Разрешение на строительство давалось, только если количество прихожан было достаточное для содержания церкви и причта.

Финансирование - важная сторона вопроса, которая тоже влияла на принятие решения епархиальными властями. Необходимо было быть уверенными, что строительство будет доведено до конца, а не приостановится из-за отсутствия денежных средств, а также, что таковых средств хватит и на благоустройство храма, и на постройку церковных зданий. Никаких специальных проверок собранных сумм не проводилось. Видимо, просто суммировались предоставленные в прошении данные. Если же были какие-то неясности, то для их разъяснения посылался запрос благочинному, который узнавал и доносил мнение строителей до Консистории. В зависимости от финансирования решался вопрос и о том, будет ли церковь самостоятельной или приписной. Типичным примером ответа благочинного по решению вопроса о возможности строительства новой церкви является следующее свидетельство о. Сергия Леонардова: «...честь имею донести Консистории, что просители на запрос относительно обеспечения в содержании и имеющего быть при церкви причта дали следующий свой ответ: «...вновь предполагаемая церковь будет приписная к своей приходской села Пушкина церкви, где имеется двойной комплект священноцерковнослужителей, посему обеспечение причта от просителей никакого не будет. Помещение же для приезда причта, если оное окажется необходимым, то просителями <...> будет выстроено. Покорнейше донося о сем Московской Духовной Консистории представляю при сем в Консисторию письменный ответ просителей в подлиннике» ${ }^{20}$.

Наличие земли под храм обычно не проверялось. Лишь однажды, в 1876 г., Консистория обратилась в Губернское по крестьянским делам присутствие для разъяснения, может ли приговор крестьян о передаче земли быть основанием

${ }^{19}$ ЦГА Москвы. ЦХД до 1917 года. Ф. 203. Оп. 449. Д. 8. Л. 8.

${ }^{20}$ Там же. Оп. 468. Д. 2. Л. 8. 
для прошения высочайшего соизволения на укрепление данной земли за храмом $^{21}$. Из МВД ответили на данный вопрос положительно.

По уставу духовных консисторий необходимо было следить, «чтобы места для церкви избирались удобные - на площадях, а не посреди обывательских строений» ${ }^{22}$ и «прилично ли и удобно ли место, на котором предполагается воздвигнуть церковь» ${ }^{23}$. Для исполнения этого в указе благочинному предписывалось, кроме описания необходимости построения храма, сообщить о том, насколько данная местность подходит для этого дела.

Посвящение церквей законодательно никак не регламентировалось, поэтому вопросов на этот счет у духовной власти не возникало. Исключение составляли случаи, когда просители это не указывали. В таком случае Консистория постановляла: «...от просителей истребовать сведение, какого наименования будут престолы в новой каменной церкви...» ${ }^{24}$. Эта информация была необходима для того, чтобы выдать строителям храмозданную грамоту.

Планы будущей церкви и территории, на которой она будет возведена, отправлялись на проверку в Строительное отделение Московского Губернского правления, которое рассматривало его с профессиональной точки зрения. В ответ отделение обычно присылало одобрение с припиской о том, что работы должны быть произведены строго по предоставленному плану и под надзором техника ${ }^{25}$. Если план был составлен неверно или требовалось уточнить какие-то детали, Консистория получала прошение донести об этом архитектору или пригласить его явиться в Строительное отделение для разъяснений.

Исключительный случай произошел в селе Люблино, где для принятия решения не пришлось обращаться в Строительное отделение: купцы приобрели уже готовый деревянный храм на выставке в Москве ${ }^{26}$. Консистория одобрила такой вариант, который был во всех отношениях очень удобным: приобреталось не только само здание, которое было уже спроектировано и построено, но и все убранство.

Архитектурный стиль не запрашивался и не проверялся: из планов должен был быть понятен стиль, да и стоит предположить, что епархиальный архитектор знал о рекомендациях, существовавших в комментариях к уставу духовных консисторий: «При составлении проектов на построение православных церквей преимущественно и по возможности должен быть сохранен вкус древнего византийского зодчества (Т. ХІІ уст. строит. ст. 218)» ${ }^{27}$. Там же предлагалось взять за основу альбом с чертежами К. Тона ${ }^{28}$. Сохранившиеся постройки, а также дореволюционные фотографии позволяют судить о том, что модный тогда неорусский стиль преобладал в большинстве построек, потому что Московский уезд

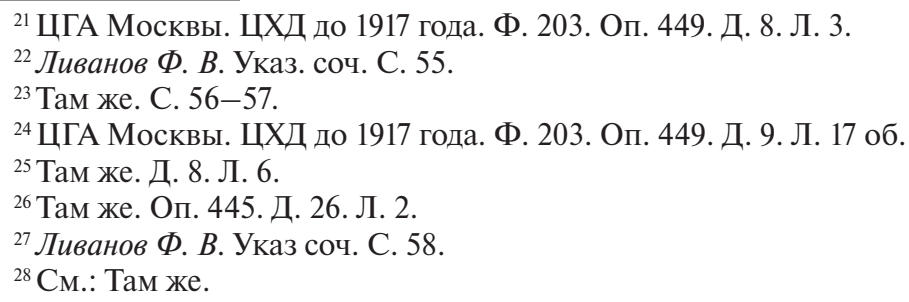


расположен совсем близко к бывшей столице, где, как и в Петербурге, в первую очередь развивались новые направления в искусстве 29 .

Кроме всех вышеозначенных проверок и запросов, Консистория делала выписки из законов, в соответствии с которыми впоследствии принималось решение. По уставу духовных консисторий архиереи имели право самостоятельно разрешать постройку храмов на подведомственной им территории. Поэтому поступившее прошение епархиальные владыки отсылали «на рассмотрение Консистории», с чьим решением в дальнейшем они могли согласиться или нет.

После сбора и проверки всей необходимой информации составлялся протокол, куда заносились все собранные данные и все законы, руководствуясь которыми Консистория принимала решение. Такой протокол зачастую был написан очень плохим почерком, вероятно второпях, с сокращенными или вовсе недописанными словами ${ }^{30}$. Он рассматривался на очередном заседании, в ходе которого выносился окончательный вердикт: «...дозволить <...> построить вместо временной деревянной новую каменную трехпрестольную, с таковою же колокольнею, церковь...» ${ }^{31}$. Последнее обязательно согласовывалось с архиереем (иногда не только с правящим, но и с викарным), и после его одобрения сообщалось просителям и благочинному.

Во второй половине XIX - начале XX в. процесс получения разрешения на строительство храма был небыстрым, но конечным. Он мог длиться от нескольких месяцев до нескольких лет. Помимо сбора денег, нахождения места и подготовки планов до подачи прошения строителям приходилось ждать, пока Консистория проверит все данные и вынесет решение. Основным критерием, которым руководствовалась духовная власть при принятии решения, было материальное обеспечение духовенства. Именно способность будущих прихожан собрать нужное количество денег на постройку и обустройство церкви, а также их возможность содержать причт являлись решающими доводами для разрешения постройки.

Ключевые слова: церковное строительство, духовная консистория, прошение, жертвователи, архитектурный план, материальное обеспечение храма и духовенства.

\footnotetext{
${ }^{29}$ См.: Бицадзе Н. В. Храмы неорусского стиля: идеи, проблемы, заказчики. М., 2009. С. 6.

${ }^{30}$ ЦГА Москвы. ЦХД до 1917 года. Ф. 203. Оп. 468. Д. 2. Л. 11-12.

${ }^{31}$ Там же. Оп. 449. Д. 9. Л. 17.
} 


\section{THE PERMIT FOR CHURCH'S BUILDING \\ IN THE POST-REFORM RUSSIA \\ (ON THE EXAMPLE OF THE MOSCOW REGION) \\ S. FEDoseEva}

This article analyses the process of getting permission for building new churches of the after-reform period. The source of the present research is the archival cases about the church building which are kept in the Moscow Central State Archive. The author distinguishes three stages in the described process: submitting the documents, checking the information and arriving at decisions. First, the petitioners submitted their requests with the detailed personal data, about the reasons for building a new church, about the source and the amount of the financing, about the availability of the land for the church construction, about the consecration of the altar, and the plan of the building and the area. The commission arrived at the decision about permitting or rejecting to build a certain church taking into consideration all these factors. The author comes to a conclusion that the main factor in such decisions for the church authority was the material security of a priest, the ability of a parish to financially support a church construction, to maintain the church itself and the clergy of the parish. The process described in the article helps to supplement our knowledge about the parish creation, and to understand the scale of the problem of maintaining the clergy which has an influence even on this aspect of the parish life.

Keywords: church construction, consistory, request, benefactor, architectural plan, the material security of a church and a priest.

\section{Список литературы}

1. Бицадзе Н. В. Храмы неорусского стиля: идеи, проблемы, заказчики. М., 2009.

2. Богословский В. Г. Очерк движения народонаселения Московского уезда Московской губернии. М., 1900.

3. Осипов E. A. Очерк статистики народонаселения Московского уезда // Сборник статистических сведений по Московской губернии. М., 1878. Т. 1. Вып. 11. 